University of Nebraska - Lincoln

DigitalCommons@University of Nebraska - Lincoln

3-1959

\title{
An Electrophoretic Study of Egg-White Proteins in Twenty-Three Breeds of the Domestic Fowl
}

Charles G. Sibley

Cornell University

Paul A. Johnsgard

University of Nebraska-Lincoln, pajohnsgard@gmail.com

Follow this and additional works at: https://digitalcommons.unl.edu/johnsgard

Part of the Ornithology Commons

Sibley, Charles G. and Johnsgard, Paul A., "An Electrophoretic Study of Egg-White Proteins in TwentyThree Breeds of the Domestic Fowl" (1959). Paul Johnsgard Collection. 4.

https://digitalcommons.unl.edu/johnsgard/4

This Article is brought to you for free and open access by the Papers in the Biological Sciences at DigitalCommons@University of Nebraska - Lincoln. It has been accepted for inclusion in Paul Johnsgard Collection by an authorized administrator of DigitalCommons@University of Nebraska - Lincoln. 


\title{
AN ELECTROPHORETIC STUDY OF EGG-WHITE PROTEINS IN TWENTY-THREE BREEDS OF THE DOMESTIC FOWL
}

\author{
CHARLES G. SIBLEY AND PAUL A. JOHNSGARD \\ Department of Conservation, Cornell University, Ithaca, New York
}

\section{INTRODUCTION}

A "conservative" taxonomic character is one which preserves evidence of evolutionary relationships. As Mayr (1942: 296) points out such characters are rare because structures are usually lost quickly when no longer needed and selection seldom neglects a functional structure for very long but continually modifies it as adaptive fitness is increased. However, because different characters evolve at different rates it is possible to find some characters which have changed more slowly than others and to use these as phylogenetic indicators. In birds, for example, plumage color and structure apparently change more rapidly than the skeleton or the muscular system. This is demonstrated by studies such as that of Hudson and Lanzillotti (1955) on the wing muscles of the Corvidae. In 19 species representing 14 genera of crows, nutcrackers, magpies and jays the wing musculature showed "remarkable uniformity" and the small differences noted did "not suggest any taxonomic groupings." The wing musculature in this instance was a conservative family level character which had not been basically modified during the evolutionary changes involved in the proliferation of the species which were studied.

Under domestication it is possible to accelerate hereditary changes by artificial selection (Lerner, 1958). In the Domestic Fowl (Gallus gallus) a remarkable array of characters has been established as the traits of different "breeds," many of them within the past century or two. The various breeds range in size from tiny bantams weighing less than two pounds to large exhibition varieties weighing ten or 12 pounds. Body shapes range from the slim "game" breeds to the heavy-bodied, meat-producing types. Plumage variations in color and form are remarkable and include the continually growing central rectrices of the Phoenix Fowl. Other breeds are characterized by crests, feathered feet, "silky" plumage and other variations. The Houdan has a double hind toe and a "split" comb. The wild ancestral Jungle Fowl has a well-defined breeding period and clutch size, but some domesticated breeds lay almost continuously and have nearly lost their brooding tendencies. Breeds vary in their resistance to disease, parasites and vitamin deficiencies; in egg size, egg shape, egg color, hatchability and freedom from blood spots in the eggs (Lerner, 1958). Variations are also found in dominance tendencies and in the frequency with which the various male displays are given (Williams and McGibbon, 1955).

It seems likely that no important feature of the Domestic Fowl has remained entirely exempt from modification. If the various breeds were judged 
taxonomically on a purely morphological basis they would certainly constitute many species and several genera. In this situation the search for "conservative" characters is especially difficult and only those features important for survival or which have not been singled out by artificial selection are likely to show stability.

\section{THE EGG-WHITE PROTEINS}

It might be expected that the composition of such substances as the egg white would not be affected by selection for size, color, etc., but the possibility of pleiotropic effects cannot be disregarded. In an electrophoretic study of egg-white proteins of 37 species of birds McCabe and Deutsch (1952) found no evidence of differences among several breeds of chickens, but no systematic study had been made.

Therefore, an investigation of protein composition, as determined by paper electrophoresis, was initiated.

\section{METHODS AND MATERIALS}

Fresh eggs from three hens of each of the following eight breeds were obtained: Rhode Island Red, Barred Rock, Cornish Game, Partridge Plymouth Rock, White Leghorn, Houdan, Brown Leghorn and New Hampshire Red. Total number of eggs sampled from each of these breeds ranged from 25 to 28. In addition, from one to three eggs were sampled from the Red Jungle Fowl, Light Brahma Bantam, Black-tailed Japanese Bantam, Old English Black Red Bantam, Gray Japanese Bantam, Plain Mille Fleur Bantam, Old English Spangled Bantam, Black Java, Silver Leghorn, Golden Pencilled Hamburg, Rhode Island Red Bantam, Partridge Wyandotte Bantam, Sultan, Old English Black Bantam, and Dark Cornish Bantam.

The eggs were opened at one end and a sample of the thin outer albumen was obtained by filtration through coarse cheese cloth. This technique prevented the thicker layer of albumen, which contains a higher percentage of the glycoprotein ovomucin, from entering the sample. Since ovomucin is insoluble in barbital buffer and precipitates out at the point of application, its presence only made the take-up of the sample by a micro-pipette more difficult and was therefore undesirable. The samples were placed under refrigeration until they were used.

The electrophoretic apparatus used was manufactured by the Spinco Division of Beckman Instruments, Inc., and consisted of a standard "Durrum" cell (Model R), a constant current power supply ("Duostat") and associated equipment for dyeing, rinsing and fixing the paper strips. The buffer used was the Spinco B-2, consisting of a mixture of diethyl barbituric acid and sodium diethyl barbiturate to provide a liter of solution with a $\mathrm{pH}$ of 8.6 and an ionic strength of 0.075 . All separations were made at a constant current of eight milliamperes per cell during a period of 16 hours at room temperature.

Six microliters of thin albumen were placed on each of the eight strips $(30 \times 305 \mathrm{~mm}$.) and following the 16 hour separation the strips were dried in 
a forced air convection oven at approximately $120^{\circ}$ Centigrade, dyed in bromphenol blue (six hours), then rinsed, fixed and dried according to the procedure specified by the manufacturer (Spinco, Procedure A).

The resulting dyed strips were analyzed by the Spinco "Analytrol" (Model RB) which "translates" the protein components into a pen-drawn curve, with the height of the curve being in direct proportion to the protein density at any given point.

\section{RESULTS}

The profiles in figure 1 represent typical curves obtained from each of the eight breeds from which 25 or more eggs were obtained. The superimposed histograms indicate the percentage of total protein found in each centimeter unit, with a scale of three per cent for each centimeter of vertical height. These percentages were obtained by means of the automatic integrator of the "Analytrol," which provides an index to the area subtended by the electrophoretic profile trace. The profiles of the other 15 breeds, from which fewer eggs were available, fall within the range of variability indicated in figure 1. Figure 2 presents the average percentage of total protein in each centimeter of the profiles of 244 eggs from all 23 breeds.

Figure 1 indicates the similarity in the electrophoretic patterns among all of the breeds sampled. All breeds show a small cathodally migrating portion, which contains the enzyme lysozyme. This component tends to move a maximum of about three centimeters from the point of application and makes up about eight per cent of the total protein profile.

A slight peak is sometimes present immediately above the point of application which indicates the presence of the insoluble ovomucin not entirely removed through filtration. A non-filtered sample would show a much higher percentage of this component, and thus its amount is not of significance in this comparison.

The first major peak is found in all cases to be at the first anodal centimeter. This is the ovoconalbumin fraction. Anodal centimeter one averaged about 16 per cent of the total protein profile. Longsworth et al. (1940) found that the ovoconalbumin fraction averaged about 14 per cent of the total albumen protein (excluding ovomucin), which does not differ greatly from our results.

The second, lower anodal peak, which is found at about anodal centimeter two, represents the ovomucoid fraction. This fairly discrete component also contributes about 14 per cent of the total soluble albumen protein (Longsworth et al., 1940).

Between anodal centimeters three to five are found small amounts of protein which do not separate into distinct fractions. These apparently represent, in addition to "tailing" of the ovalbumin, the globulin fractions $G_{2}$ and $G_{3}$. The poor separation of these components in all the breeds studied probably resulted from an unsatisfactory $\mathrm{pH}$ and the resolution limitations of the filter paper medium. 

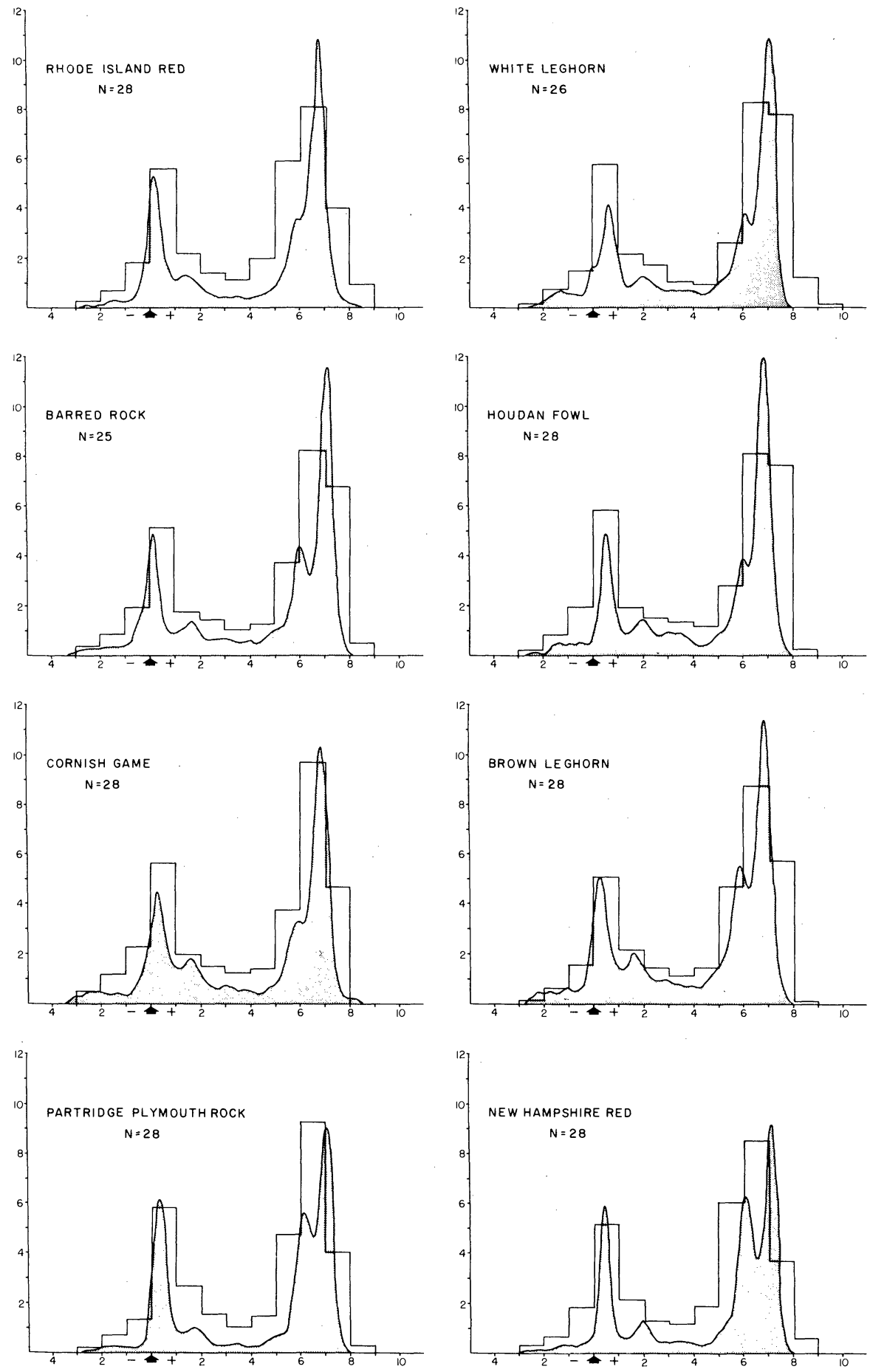

FIGURE 1. Typical electrophoretic profiles of the egg-white proteins of eight breeds of domestic fowl. The histograms indicate the percentage of total protein in centimeter units. Eack centimeter on the vertical axis $=3 \%$. 
The remainder of the profile consists of the major component, ovalbumin. As the figures indicate, this is actually composed of two major portions, ovalbumin $A_{1}$ and $A_{2}$, the latter usually appearing as a "shoulder" on the trailing edge of the major $A_{1}$ peak. Some samples independent of breed, showed a distinct tendency of the $A_{1}$ peak to separate into two components, the second appearing on the leading edge of the major peak. These variations are known to be due to differences in phosphorus content (Perlmann, $1950 ; 1952)$ and the different ovalbumins differ from one another in one or two phosphoric acid residues (Fevold, 1951; Warner, 1954).

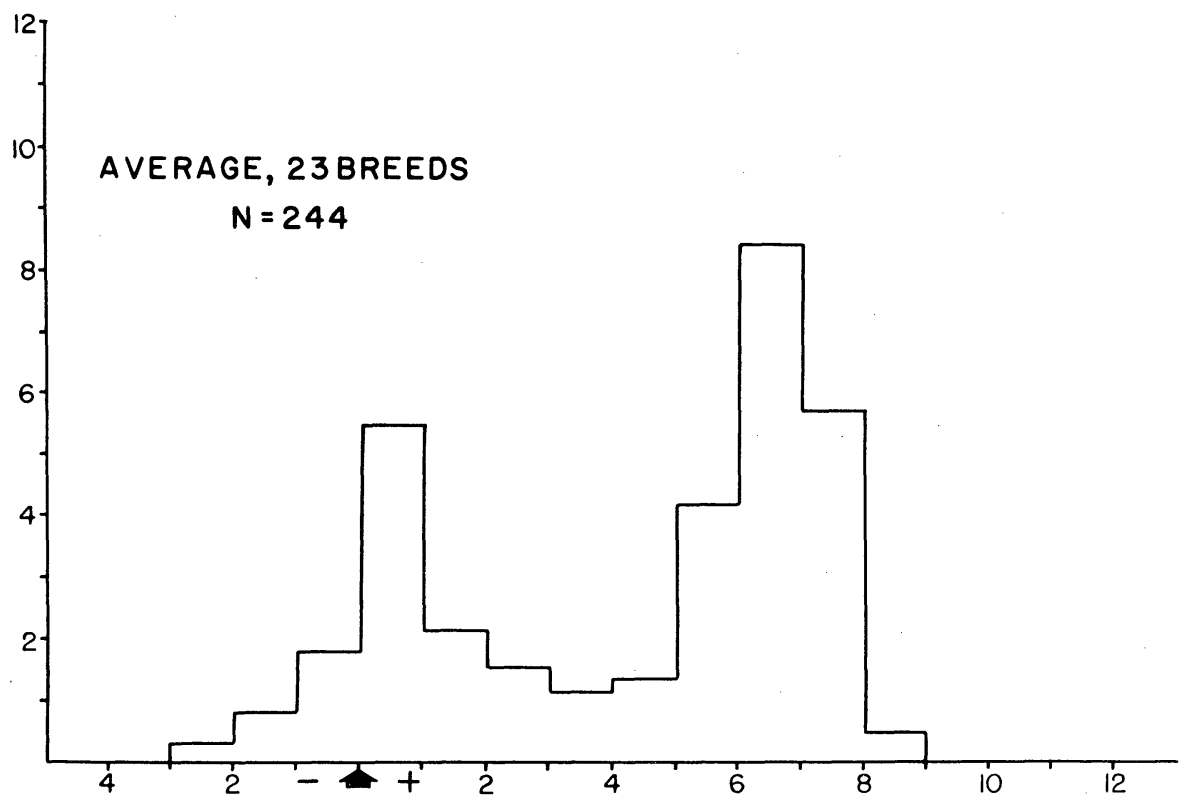

FIGURE 2. Average percentage of total protein in centimeter units for 244 eggs from 23 breeds of domestic fowl. Each centimeter on the vertical axis $=3 \%$.

According to Longsworth et al. (1940) the total ovalbumin fraction comprises about 60 per cent of the albumen protein. Average percentages obtained by us for the eight major breeds studied were about 57 per cent. Albumin "tailing" losses on the paper medium probably account for the slight differences found.

To provide a more precise method for comparing the major breeds studied, the average percentage of total protein per centimeter in both directions from the point of application was calculated and is presented in table 1 . These data, from which the histograms were derived, indicate the generally small amount of variability found in the protein profiles of the breeds studied. Only in two places do these figures show greater variability than might be expected from sampling errors and the quantitative limitations of the technique. These are in anodal centimeters 6 and 8 , where average deviations 
TABLE 1

AVERAGE PERCENTAGE OF TOTAL PROTEIN PER CENTIMETER

\begin{tabular}{|c|c|c|c|c|c|c|c|c|c|c|c|c|c|c|c|}
\hline \multirow{2}{*}{ Breed } & \multirow{2}{*}{$\mathrm{N}$} & \multicolumn{14}{|c|}{ Centimeters from point of application } \\
\hline & & -4 & -3 & -2 & -1 & +1 & +2 & +3 & +4 & +5 & +6 & +7 & +8 & +9 & +10 \\
\hline \multicolumn{16}{|l|}{ Partridge } \\
\hline Plymouth Rock & 28 & .05 & .78 & 1.98 & 4.04 & 17.41 & 7.68 & 4.74 & 3.16 & 4.28 & 13.93 & 28.11 & 12.45 & 1.26 & .01 \\
\hline White Leghorn & 26 & .13 & .57 & 2.04 & 4.34 & 16.94 & 6.91 & 4.79 & 3.11 & 2.72 & 7.59 & 24.74 & 23.23 & 3.53 & .01 \\
\hline \multicolumn{16}{|l|}{ Rhode Island } \\
\hline Red & 28 & .03 & .67 & 2.15 & 5.41 & 16.26 & 6.37 & 4.13 & 3.26 & 5.84 & 17.39 & 24.05 & 11.88 & 2.62 & .09 \\
\hline Barred Rock & 25 & .12 & 1.22 & 2.31 & 5.68 & 15.31 & 5.52 & 4.26 & 3.14 & 3.70 & 11.33 & 25.00 & 20.57 & 1.76 & .00 \\
\hline Cornish Game & 28 & .09 & 1.30 & 3.17 & 6.67 & 16.71 & 5.84 & 4.40 & 3.73 & 4.02 & 11.04 & 28.78 & 14.54 & .04 & .00 \\
\hline Houdan & 28 & .00 & .36 & 2.43 & 5.71 & 17.51 & 5.63 & 4.47 & 3.92 & 3.52 & 8.26 & 24.31 & 22.95 & .81 & .00 \\
\hline \multicolumn{16}{|l|}{ New Hampshire } \\
\hline Red & 28 & .09 & .60 & 1.70 & 5.42 & 15.46 & 6.55 & 3.90 & 3.65 & 5.77 & 18.21 & 25.49 & 11.22 & 1.88 & .00 \\
\hline Brown Leghorn & 28 & .00 & .43 & 2.05 & 4.72 & 15.35 & 6.81 & 4.62 & 3.63 & 4.77 & 13.97 & 26.43 & 17.17 & .38 & .00 \\
\hline \multirow{2}{*}{$\begin{array}{l}\text { Ave., } 8 \text { breeds } \\
\text { Ave. Deviation } \\
\quad 8 \text { breeds }\end{array}$} & 219 & .06 & .74 & 2.23 & 5.25 & 16.37 & 6.32 & 4.41 & 3.45 & 4.29 & 12.71 & 25.86 & 16.75 & 1.53 & .01 \\
\hline & 219 & .04 & .36 & .31 & .66 & .77 & .53 & .23 & .27 & .80 & 3.16 & 1.43 & 4.22 & .91 & .02 \\
\hline \multirow{2}{*}{$\begin{array}{l}\text { Ave., } 23 \text { breeds } \\
\text { Ave. Deviation } \\
23 \text { breeds }\end{array}$} & 244 & .06 & .75 & 2.25 & 5.25 & 16.26 & 6.35 & 4.45 & 3.48 & 4.24 & 12.45 & 25.92 & 17.13 & 1.40 & .01 \\
\hline & 244 & .04 & .26 & .30 & .59 & .81 & .48 & .26 & .26 & .76 & 3.15 & 1.32 & 4.26 & .91 & .02 \\
\hline
\end{tabular}

23 breeds 
from the mean combined breed profile are approximately three and four per cent. This results from the fact that these points represent the leading and trailing edges of the major ovalbumin fraction, and minor variations in the total distance moved by this fraction greatly affect the amount of protein to be found in these two centimeter units. Thus the percentage protein for centimeter six tends to be high in some breeds (Rhode Island Red, New Hampshire Red) and correspondingly low in centimeter eight, or the reverse situation may obtain as in the White Leghorn and Houdan Fowl.

\section{DISCUSSION AND CONCLUSIONS}

The variation encountered in the egg-white proteins of the 23 breeds studied was no greater than can be explained on the basis of individual variation and sampling and measuring errors, and is not correlated in any observable way with breed differences. The variations are no greater than one would obtain in the measurement of the classical anatomical features of plumage, size and shape of body and skeleton, or other features usually used by taxonomists in characterizing a species. In this regard, the eggwhite proteins show the same stability which Yamashina (1944) found in chromosome number and morphology of 17 varieties of Domestic Fowl. Thus selection for external morphological characters does not necessarily affect the basic protein structure, and evidence of phylogenetic relationships may be conserved in the proteins after it has been obscured in more superficial characters by the effects of selection for "signal" characters or other functions.

The electrophoretic profiles of the egg-white proteins of more than 360 species of birds have been studied up to November, 1958, including some 30 species of the family Phasianidae which includes the Domestic Fowl (Sibley, in press). The similarity in pattern which extends through groups of related species is striking and further indicates the phylogenetic conservatism of the egg-white proteins. For example, the profiles of the Turkey (Meleagris gallopavo) and Ring-necked Pheasant (Pbasianus colchicus) are similar to that of the Domestic Fowl. These three species, although considered on morphological grounds to represent three separate genera, show a high degree of interfertility. Hybrids between Gailus and Phasianus are not uncommon and Meleagris $\times$ Phasianus hybrids have been produced by Asmundson and Lorenz (1955, 1957). Meleagris $\times$ Gallus hybrids have not yet been brought to hatching although fertility is fairly high and 22-day embryos have been obtained. Sokolow et al. (1936) have reported that the chromosomes of the Turkey and Ring-necked Pheasant are more alike than those of the Pheasant and Domestic Fowl. All of these lines of evidence suggest a closer relationship among these three species than is indicated by external morphology. Exactly parallel cases are found in the ducks of the genus Anas and doves of the genus Streptopelia.

The evolutionary conservatism of proteins has also been demonstrated at the most fundamental structural level by the important work of Sanger and his colleagues (Brown, Sanger and Kitai, 1955; Harris, Sanger and Naughton, 
1956) in their studies of the amino acid sequence in the insulin molecule. The insulins of five mammalian species have been worked out and such differences as exist are all located in one small segment of the molecule. In commenting on the taxonomic value of proteins Crick (1958) suggests that the structure of these molecules may contain "the most delicate expression possible of the phenotype of an organism and that vast amounts of evolutionary information may be hidden away within them."

\section{SUMMARY}

Fresh albumen samples from a total of 244 eggs from 23 breeds of Domestic Fowl (Gallus gallus) were analyzed electrophoretically. These breeds include the wild-type Red Jungle Fowl, as well as a wide variety of bantam, laying, and exhibition breeds which provide a large amount of morphological and physiological diversity. No variation in the egg-white proteins among these breeds could be detected that was greater than normal sampling and measuring errors inherent in the technique. It is concluded that the structure of the egg-white proteins is phylogenetically conservative.

\section{ACKNOWLEDGMENTS}

We are indebted for assistance with the laboratory work to Miss Philippa Claude. The National Science Foundation has supported this work (NSF G-1832 and G-4562), and the New York State College of Agriculture at Cornell University has provided facilities and equipment.

We are grateful to the Cornell University Department of Poultry Husbandry which provided the eggs of the first eight breeds listed and to Mrs. Florence Ray of Horseheads, New York, who provided the eggs of the other 15 breeds.

\section{LITERATURE CITED}

Asmundson, V. S., and F. W. Lorenz, 1955, Pheasant-turkey hybrids. Science 121: 307-308.

1957, Hybrids of ring-necked pheasants, turkeys, and domestic fowl. Poultry Sci. 36: 1323-1334.

Brown, N. H., F. Sanger and R. Kitai, 1955, The structure of pig and sheep insulins. Biochem. Journ. 60: 556-558.

Crick, F. H. C., 1958, Protein synthesis. pp. 138-163 in The biological replication of macromolecules. Symp. Soc. Exp. Biol. 12. Academic Press, New York.

Fevold, H. L., 1951, Egg proteins. pp. 187-252 in Advances in protein chemistry, vol. VI, ed. by M. L. Anson, J. T. Edsall and K. Bailey.

Harris, J. I., F. Sanger and M. A. Naughton, 1956, Species differences in insulin. Arch. Biochem. Biophys. 65: 427-438.

Hudson, G. E., and P. J. Lanzillotti, 1955, Gross anatomy of the wing muscles in the Family Corvidae. Amer. Midl. Nat. 53: 1-44.

Lerner, I. M., 1958, The genetic basis of selection. John Wiley \& Sons, New York.

Longsworth, L. G., R. K. Cannan and D. A. MacInnes, 1940, An electrophoretic study of the proteins of egg white. Jour. Am. Chem. Soc. 62: 2580-2590.

Mayr, E., 1942, Systematics and the origin of species. Columbia University Press, New York.

McCabe, R. A., and H. F. Deutsch, 1952, The relationships of certain birds as indicated by their egg white proteins. Auk 69: 1-18.

Perlmann, G. E., 1950, Enzymatic dephosphorylation of ovalbumin and plakalbumin. Nature 166: 870-871. 
1952, Enzymatic dephosphorylation of ovalbumin and plakalbumin. Jour. Gen. Physiol. 35: 711-726.

Sibley, C. G., (in press), The electrophoretic patterns of egg-white proteins as taxonomic characters.

Sokolow, N. N., G. G. Tiniakow and J. E. Trofimov, 1936, On the morphology of the chromosomes in Gallinaceae. Cytologia 7: 466-489.

Warner, R. C., 1954, Egg proteins. pp. 435-485 in The proteins, vol. II, part A, ed. by H. Neurath and K. Bailey. Academic Press, New York.

Williams, C., and W. H. McGibbon, 1955, Courtship behavior of the male Domestic Fowl, Gallus domesticus. Poultry Sci. 34: 1172-1173.

Yamashina, Y., 1944, Karyotype studies in birds. I. Comparative morphology of chromosomes in seventeen races of Domestic Fowl. Cytologia 13: 270-296. 